\title{
Challenges and Opportunities for Sustainable Urban Farming in South African Low-Income Settlements: A Case Study in Durban
}

\author{
Iwona Bisaga $^{1, *(\mathbb{D}}$, Priti Parikh ${ }^{1}\left(\mathbb{D}\right.$ and Claudia Loggia ${ }^{2}$ \\ 1 UCL Civil, Environmental and Geomatic Engineering Department, University College London, Chadwick \\ Building, London WC1E 6BT, UK; priti.parikh@ucl.ac.uk \\ 2 UKZN School of Built Environment and Development Studies, University of KwaZulu-Natal, Howard \\ College Campus, Durban 4001, South Africa; Loggia@ukzn.ac.za \\ * Correspondence: i.bisaga.12@ucl.ac.uk; Tel.: +44-74-4618-5171 or +25-07-8991-5533
}

Received: 16 August 2019; Accepted: 10 October 2019; Published: 14 October 2019

check for updates

\begin{abstract}
Growing urban centres have been attracting ever higher numbers of rural migrants, including small-scale farmers, looking for better opportunities due to the rise of large-scale farming, loss of land and climate change. Consequently, there has been an increase in the number of spontaneous and informal settlements being constructed as cities do not keep up with the planning and infrastructure development for new arrivals. Urban dwellers in informal, unplanned settlements where issues of land tenure and access to services are prevalent have, consequently, been exposed to precarious living conditions with limited access to food and water scarcity. Urban agriculture (UA) strategies have been adopted by those residents to alleviate poverty and food insecurity, and have been seen to perform other functions, such as environmental, social, cultural and developmental. This study explores challenges and opportunities for sustainable urban farming as an integrated environmental management strategy for the upgrading of informal settlements in three case studies in Durban. This paper demonstrates the need for municipalities to support community driven processes to ensure sustainability of UA initiatives and sustained investment for maintenance. Policy makers need to create an enabling environment for academics, non-governmental organizations (NGOs) and the private sector to co-develop water efficient solutions to manage the food-water nexus and capitalise on localised community structures and groups, such as co-operatives and women groups.
\end{abstract}

Keywords: urban agriculture; informal urbanisation; environmental management; women farmers; South Africa

\section{Introduction}

Urbanisation has been one of the main defining forces of the past century. Currently, over 50\% of the population live in cities and towns with a prediction of that number increasing to $60 \%$ by 2030 [1]. Most of the urban growth is concentrated in Africa and Asia, the former experiencing rapid urban transitions across the continent and the projected number of the global share of African urban dwellers by 2050 is set to reach $20.2 \%$ [2]. Growing urban centres being perceived as places of better opportunities have been attracting ever higher numbers of rural dwellers, including youth and small-scale farmers, often struggling due to the rise of large-scale farming, loss of land and climate change [2]. Consequently, there has been an increase in the number of spontaneous and informal settlements being constructed as cities do not keep up with the rapid pace of urbanisation. According to UN-Habitat [3], informal settlements are home to over half of the urban poor in developing nations, with a figure of over $60 \%$ in African cities. In South Africa (SA), informal settlements are home to a growing number of people, outpacing that of the growth of formal housing [4]. According to the 
Socio-Economic Rights Institute of South Africa (SERI) [5], around 65\% of the population lives in urban centres, with one in every five households living in informal settlements.

These trends have put a lot of pressures on cities and their limited resources, such as land and water, and their infrastructures which frequently have not been keeping up with the pace of change. The urban poor in informal, unplanned settlements where issues of land tenure and access to services are prevalent, have consequently been exposed to often precarious living conditions and with limited food and access to water resources, ever more people have been engaging in informal activities [6]. Urban agriculture (UA) strategies have been adopted by poor urban residents to alleviate poverty and food insecurity, and have been seen to perform other important functions, such as environmental, social, cultural and developmental [7].

As part of the Economic and Social Research Council (ESRC)- and National Research Foundation (NRF)-funded project ISULabaNtu, the authors explored challenges and opportunities for sustainable urban farming as an integrated environmental management strategy for the upgrading of informal settlements in SA. By applying action research methods, this study collected community perceptions around the implementation of UA in three low-income settlements in Durban. This paper seeks to answer the following questions: i) what does UA mean for the residents of low-income settlements?; ii) what environmental, economic and social challenges and opportunities can be identified for the implementation of UA in the context of such settlements?; and iii) which groups can benefit the most from UA activities and with what kind of support? By doing so, the paper contributes to the current debate on UA, particularly in the context of low-income settlements in urban and peri-urban areas, where knowledge gaps around the design, implementation and sustainability of such initiatives still exist. Therefore, it seeks to expand the knowledge base on trade-offs between the need for food production and water scarcity in rapidly urbanising settings which is arguably going to become a critical component of urbanisation, particularly in sub-Saharan Africa.

Firstly, this paper sets the context of low-income and informal settlements, with a focus on SA (Section 2). Then the study seeks to investigate definitions and benefits of UA (Section 3), followed by a review of literature on UA in SA and in eThekwini. Section 4 outlines the research methodology and introduces the case study sites. It is followed by findings in Section 5. Here, other examples of UA projects in eThekwini are explored to further analyse success and failure factors of such initiatives. Key challenges and opportunities for UA are discussed in Section 6. Finally, the conclusion and recommendations are provided in Section 7. This research applies the sustainability of UA conceptual framework proposed by van den Berg [8] in order to systematically organise the findings from fieldwork conducted between May 2017 and July 2018 and guide the discussion.

\section{Low-Income and Informal Settlements}

Informal settlements are characterised by self-help efforts, often illegal, and are considered 'informal' as they do not align with prevailing regulations. In these unplanned settlements, residents use the limited resources available to them to erect shelter on interstitial or marginal land [9], often close to economic, social or survival benefits. Informal settlements are complex, popular and spontaneous neighbourhoods that offer an immediate response to housing, and their location is critical for the socio-economic activities of the involved community [10]. Interestingly, Roy [11] suggests a more progressive interpretation of informal settlements as being spaces of habitation, livelihood, self-organisation and politics. This concept moves away from the pathology of informal settlements, envisaging their potential as dynamic places of living.

Low-income households can be defined as those where the consumption rate is below the poverty line. In 2018, Statistics South Africa updated a set of three national poverty lines: the food poverty line (FPL), lower-bound poverty line (LBPL) and upper-bound poverty line (UBPL), which are to be used for poverty measurement in the country [12]. The FPL is set as an income of R547 (around 30 GBP) per person per month, commonly referred to as the "extreme" poverty line. In this research, we are looking at low-income households under the FPL. The low-income group has also been classified by 
the Parliament of the Republic of South Africa [13] as eligible for a subsidised house (RDP), having an income below 3500 ZAR (190 GBP).

Townships and informal settlements in SA are a result of rapid urbanisation as well as a legacy of the apartheid policies of the past, often represented by notions of informality focusing on uncertainty and uncontrollability, and the lack of capacity to lift oneself out of poverty, disregarding the relational character of poverty [14]. Despite those settlements being frequently studied at the level of individual households, they are complex social structures with varied levels of self-organisation and community cohesion. Informal settlement upgrading efforts only brought community participation and planning to the fore in early 2000s, replacing the predominant elimination and eradication approach of the previous decades [15].

In SA, a community-driven approach called the People's Housing Process (PHP) was adopted in 1998. The PHP approach to housing provision, inspired by the work of the South African Homeless People's Federation and saving and housing schemes from around the globe, has been a feature of national policy. However, many provinces resisted it in favour of private sector delivery [16]. Then, in 2008, a new policy called the Enhanced People's Housing Process (EPHP) was adopted to replace the previous PHP programme. The EPHP proposes that beneficiaries actively participate in decision-making over the housing process to achieve some important targets, such as empowering the dwellers, creating partnerships, mobilising and retaining social capital, promoting local economic development, fostering stable communities, involving women and youth more directly, and creating sustainable and inclusive human settlements which are more responsive to the needs of the community [17]. In fact, a sustainable human settlement should provide not only dwelling units, but also a safe and healthy environment, while encouraging sustainable livelihoods within the broader neighbourhood. From this perspective, UA offers opportunities to create sustainable human settlements.

\section{Urban Agriculture (UA)}

\subsection{Definitions and Benefits}

UA may include activities in urban settlements where people use land and other resources such as water and available germplasm (crops and animals) to produce food and food products for their own consumption and/or for sale to residents/consumers living in close proximity.

A broad definition of UA was introduced by the United Nations Development Programme (UNDP), which describes UA as "[ ... ] an activity that produces, processes and markets food and other products, on land and water in urban and peri-urban areas, applying intensive production methods and reusing natural resources and urban wastes, to yield a diversity of crops and livestock" [18] (p.11).

As far back as 1987, the World Commission on Environment and Development (WCED) urged governments to consider supporting the inclusion of UA into development planning, stating that "[it] could become an important component of urban development and make more food available to the urban poor" and become a source of additional income to supplement budgets [19] (p.171). Despite mixed perceptions, some of which deem it inconsequential and unable to face the scale of the urban challenges, UA has been gaining importance in the last decade. Zeunert and Waterman [20] have postulated that UA is far from insignificant and offers financial, environmental and social benefits. It can boost sustainability prospects as well as enhance self-reliance of informal settlement dwellers who can complement their food supplies through small-scale, either individual or collective, agricultural activities thus reducing the reliance on cash to access sufficient food for their families [21]. Stewart et al. [22] have warned against the potential threats stemming from the increased promotion of UA. Among them, environmental and urban health risks caused by the unregulated use of wastewater which may result in contamination and spread of diseases. Other challenges associated with UA have been the availability of water resources for such activities considering the drastic increase in water demand in cities, including informal settlements [23]. Closed-loop and integrated resource 
management approaches have been proposed as ways to address challenges facing UA in order to maximise its benefits and minimise barriers.

Mougeot [24] argues that the purpose of UA can be for plant and/or animal production and either for marketing produce in proximity to urban centres (or in them directly), or for own consumption. Richter et al. [25] contend that it is not the location that defines UA but the fact that it is embedded in and interacting with the urban eco-system and its needs, and may include small and large areas within city boundaries or on its outskirts such as vacant plots, community gardens, greenhouses, indoor farms, balconies or terraces [26]. Mougeot [27] asserts six different dimensions that are associated with UA, namely: economic activities, location, areas, scale, products, and destination. As urban elements and definitions, including UA, are in constant change, revisiting them is an opportunity to increase co-operation within communities and involving them in a participatory process towards UA. This aspect of urban development is a potential asset to help diversify urban management strategies and build more resilient communities [27].

Approaching UA from a sustainability perspective brings into focus many of the Sustainable Development Goals (SDG), including zero hunger (SDG2), good health and well-being (SDG3), decent work and economic growth (SDG8) and sustainable cities and communities (SDG11), in particular. UA has an important role to play in addressing urban food insecurity problems given the food production challenges associated with rural-urban migration. It can help cities to adapt to climate change and help transition urban areas into a green, circular economy [28]. On a micro-level, it can help keep informal settlements cool, especially where corrugated iron is used as building material, and increase air quality [29]. Furthermore, UA helps diversifying local economy and sources of income, making communities more resilient to external threats, such as flooding or unemployment [27].

The importance of agriculture is that it allows production to become the source of income for the urban poor, as well as a source of food supply in low-income households. UA can potentially reduce poverty, the effect of inflation and malnutrition within the vulnerable groups, particularly women and children, by enhancing asset generation for those who partake of it. The broad definition of UA considers the role of livelihood sustainability that UA has for low-income households and acknowledges UA as a variable that brings in a source of income and empowers vulnerable groups like women through employment, setting micro-businesses or upskilling opportunities [21]. Most urban farmers are men and women with low incomes who grow produce mainly for self-consumption. This happens on small plots which are self-claimed, and often lack any support of protection [27]. However, women are more likely to be invested in saving-schemes and building individual household resilience against disasters and unexpected expenses [29]. Increasing UA possibilities within communities helps diversify household incomes and increase the agency of women. Olivier and Heinecken [30] argue that through participation in UA activities in the context of Cape Flat's NGO-run projects, women not only gain better food security but also build personal, socio-economic networks which offer support and help unlock women's potential and improve their feeling of belonging and empowerment.

The Urban Development and Resilience Unit of the World Bank [31] conducted case studies on UA in four cities: Bangalore (India), Accra (Ghana), Nairobi (Kenya) and Lima (Peru). In this context, UA was defined as an industry located within or on the fringe of a town, city, or metropolis that grows and raises, processes and distributes a diversity of agricultural products from both plants and animals, using inputs found in and around that urban area. The impacts of UA in these four cities included provision of employment and income to farmers, as well as a contribution towards food and nutritional security.

\subsection{UA in Low-Income Settlements in South Africa}

This section presents a number of UA initiatives which are reflective of the state-of-the-art of UA and its current best practices in SA. Van Averbeke [7] conducted a study in five informal settlements of Atteridgeville, Pretoria, which involved different types of urban-farming projects. Majority of participating households were engaged in urban farming in the form of home gardening, group 
gardening and dryland farming. Most active participation was observed predominantly among women. Even though the overall contribution of those activities to the households' incomes and food supplies were modest, the livelihood benefits proved to go beyond material gains only. Reduction in social alienation and family disintegration caused by urban poverty were significant, as was the improved community cohesion. Limited space and access to water for irrigation purposes were noted as the main barriers to participation in urban farming activities.

Kekana [6] investigated an agricultural project in Soshanguve (Pretoria) launched by the Agricultural Research Council (ARC) and the Gauteng Provincial Department of Agriculture (GPDA) and found that urban farming benefitted poor households not only through direct savings on food purchases but also through income-generation from the sale of produced foods. However, lack of integrated development approach to UA and its inclusion in urban land-use planning in governance was observed, thus constraining the potential of UA to create a positive impact across low-income settlements, such as Soshanguve.

Mansfield, Brillembourg and Klumpner [32] have appraised the UA and environmental action association called Abalimi which develops micro farms focusing on sustainable food production through individual and community gardens within three Cape Town townships, located in the Cape Flats, an expansive sand dune area. As of 2015, over 4000 micro farmers and 200 community projects had been registered. One of the key challenges in the settlements is the lack of land but the organisation has negotiated access to unused spaces for the residents to set up farms in, for example pieces of land where construction is prohibited, land plots around public buildings and along roads or under power lines. Community farming in those spaces has improved the quality of the environment in terms of its aesthetics and ecology. These UA systems have also provided solutions to other challenges faced by the residents, namely food insecurity, unemployment and associated societal problems. By boosting livelihood opportunities, moderately increasing food supplies for each participating household and bringing the community together to take action, as well as by providing UA and other educational opportunities, Abalimi has been found to boost social cohesion, community confidence and residents' skills, in addition to improving the environmental well-being of the settlements [32].

Frayne et al. [33] investigated the municipalities of Cape Town, Msunduzi (Pietermaritzburg) and Johannesburg, focusing specifically on the issue of food insecurity. In all three case studies, a high number of food insecure households was observed. However, in Cape Town under $5 \%$ of them grew their own food, engaging in some form of UA, and in Msunduzi high levels of contamination of the settlement area and the rivers on which they are located were prohibitive to UA activities. The need for partnerships, knowledge-building and relevant policy making were stressed as critical requirements for addressing food insecurity in all three case studies.

The challenge of food security is further enhanced by a scarcity of environmental resources, population growth and increased demand and consumption of water. [34]. There is a need for further work on understanding the feasibility of safe use of greywater for irrigation and attitudes towards such uses. A study by Bakare et al. [35] in a Durban community showed a greater willingness to use greywater for toilet flushing and garden purposes at times of drought or water scarcity, and predominantly among younger participants (20- to 29-years-old). Rodda et al. [36] evaluated the impact of medium-term sub-surface irrigation of vegetable crops with domestic greywater on soil, plant growth and yield, and microbiological quality of crops. The study concluded that greywater irrigation increased plant growth and crop yield. However, it could lead to accumulation of sodium and metals in soil with time, and hence in plant crops. Greywater irrigation could increase microbial loads on plants, although of the microorganisms investigated, only E. coli and total coliforms showed significant increases. The use of aquatic vegetation to absorb nutrients from treated wastewater is another form of nutrient harvesting. This might constitute an effective means of removing nutrients from effluents and the harvested plants can then be used directly as fertiliser or added to compost. Another investigation by Bakare et al. [37] in a community in Durban found that greywater from different households varied significantly and could not be easily treated through biological processes 
or technologies because of low mean Biochemical Oxygen Demand (BOD):Chemical Oxygen Demand (COD) ratio. Currently the Pollution Research Group (PRG) of the University of KwaZulu-Natal (UKZN), in Durban, is conducting a study on the evaluation of duckweed and Azolla spp. for biomass production, removal of $\mathrm{N}$ and $\mathrm{P}$ from decentralised wastewater treatment effluent and the potential fertiliser value of the biomass. Most of the work done on greywater for crop production is still in the research phase in SA.

\subsection{Urban Agriculture in eThekwini Municipality}

Activities and issues relating to UA in major cities such as eThekwini (Durban) have not been well-documented. UKZN have developed a draft policy review taking into consideration existing policies on urban farming guidelines, sanitation systems and resource recovery, water and sanitation, agriculture, pollution, housing and electricity. A gap between policy and implementation was noted i.e. environmentally friendly policies are in place but there are challenges in relation to acceptance, implementation on the ground and understanding of requisite management systems. Guidelines on UA such as community gardens or farms, use of vacant plots for agricultural activities and small-scale urban gardens adjacent to households are not currently provided by the eThekwini municipality, nor is systematic support to enable such activities. However, there is evidence of support and interest in UA on the part of the municipality. The drought-management fact sheet has a single advice on watering gardens at night to reduce evaporation rate of water [38]. Multiple programmes have existed to promote UA such as the eThekwini Agro-Ecology programme, that liaises with field staff in communities, promoting appropriate and sustainable approaches to UA [39]. Such programmes, conducted with communities where interest in UA has been expressed or UA activities are already taking place, can be helpful to ensure sustainability through awareness-raising, training and maximisation of benefits, whether social, economic or environmental. The vision of the Agro-Ecology programme is food sovereignty for all residents and a small-scale agro-sector which can contribute to improved health and well-being, growth of local economies and environmental sustainability [39]. The programme encompasses three key areas of focus: semi-commercial focus for activities such as community mini farms; socio-economic focus for communal gardens and co-operatives; and social focus aimed at improving food security in informal and low-income settlements [39].

The eThekwini metropolitan area has been divided into five agricultural zones to facilitate the equal distribution of resources, taking into account catchments, road access and logistics. Hubs have been established in each zone to support growers with training and inputs, these hubs include Newlands, Umbumbulu, Inchanga, Mariannhill and Northdene. Training includes 'bio-intensive' food production where the soil in main crop production beds are built through a method of double digging and adding organic composts; compost making and organic pest control. The training also offers programmes for water conservation, composting and productive use of land. According to eThekwini's Chief Horticulturist, approximately 38 people are employed at the hubs, but the real impact is in communities. The field staff currently support approximately 241 gardens representing 1896 growers.

The model of co-operatives to foster community involvement in environmental initiatives has been successful through the Sihlanzimvelo Stream Cleaning Project in the Umlazi area with three assessors monitoring and supporting 22 co-operatives maintaining a total of $110 \mathrm{~km}$ of streams and the Inanda, Ntuzuma and KwaMashu (INK) area with four assessors monitoring and supporting 37 co-operatives maintaining a total of $185 \mathrm{~km}$ of streams. With 59 co-operative contracts with the eThekwini Municipality active, the project has employed 472 workers, many of them youth, and has focused on activities such as removal of alien plants, solid waste management, water quality improvement, indigenous vegetation planning for stabilising riverine zones, increase resilience to climate change and capacity building in communities to better understand the value of natural infrastructure and the need to maintain it. 
Another notable example of an urban agricultural project is the Newlands Mashu agricultural hub located in Newlands (North Durban) [40], which is part of the Agricultural Management Unit (AMU) in the Parks Department of eThekwini Municipality and a product of a partnership between the Water and Sanitation Unit (EWS) of the eThekwini Municipality and the pollution Research Group (PRG) at UKZN. Established in 2010 to conduct integrated research on sanitation, decentralised wastewater treatment, nutrient recovery and recycling, this project has been serving as a bio-intensive vegetable production site, promoting household food security and developing solutions for closed-loop systems for the use of sanitised waste streams, such as wastewater, faeces and urine, for agricultural use [41]. One of the goals of the project is to contribute to the development of UA across SA by assessing various waste products from on-site sanitation systems through agricultural trials. As such, however, to date these solutions have not been widely adopted.

There are also examples of successful initiatives promoting and supporting UA in informal settlements and townships through NGOs. For instance, a Durban-based NGO, Aqualima Trust, has implemented 28 biogas digestors in a rural informal community Ndwedwe (I-E) through funding provided by the national government. The households (HHs) for participation in the project were selected on the basis of involvement in agricultural activity and presence of livestock which are kept in kraals (enclosures) overnight so that the dung can be readily collected. Local builders built the biogas digestors. Some of the HHs also got involved in food gardens. Land ownership was noted to be a key challenge in tribal areas as the tribal leaders (chiefs) control access to the land. Water access, required to slurry the dung, was also a challenge to operate the biogas plant. Attempts were made to collect greywater to be diverted to the biodigesters to address the water challenge, however, this was not enough so then additional water supply and piping proved to be a challenge. Also, the high upfront costs of ZAR 30000 (about 1600 GBP) to 40000 (about 2100 GBP) made it unaffordable for scale up.

In other low-income settlements, Aqualima (http://aqualima.co.za/projects.htm) have implemented rainwater harvesting systems and gravity feed low-tech irrigation systems [38]. The challenge has been the low resource base and lack of skills for maintenance to ensure that the systems work. Ongoing support is therefore required from NGOs to maintain the systems. For example, de-clogging of irrigation systems and repairs would need support of municipal teams to ensure sustainability of such schemes. It was also noted that the success of most urban farming schemes was dependent on local leadership. In some urban farming schemes, the leader would contract work to labour and run the farm as a small business. In some instances, a large plot of land would be subdivided and managed through co-operatives. The challenge often is how to share resources and the arising income. Additionally, sometimes there is a high turnover and lack of consistency of individuals who engage in farming, putting at risk the continuity and sustainability of urban farming initiatives. In KwaMashu township, where gravity flow pipes and sprinklers were installed for vegetable farming, UA has been partially successful in generating income for households although the income is less than that earned in a full-time job [42]. Yet, given the high unemployment rate of up to $30 \%$ among the youth, this offers at least an intermediary solution, but also proves that urban farming is not financially viable for all.

Another successful case of urban farming is the South Africa Development Bank project in rural Inanda (Durban) where there is a mix of formal and informal housing. The scope included community gardens, rainwater harvesting, setting up co-ops and selling crops. Rainwater was used to support farming activities. The city provided topsoil to the residents and there were enough vegetables grown to feed a local orphanage, as well as sell some of the produce. It was noted that the youth were less interested in the scheme.

\subsection{Pollution and Use of Wastewater}

The use of wastewater for agriculture, whether urban or rural, is a common practice in most developing countries [43], particularly in water-scarce areas. However, guidelines for a safe use of such resources vary, with relevant policies not always being in place and the lack of acceptability or misperceptions of wastewater posing challenges to its use in farming. As contended by Bos, Carr and 
Keraita [43], agricultural use of untreated or partially treated wastewater is common. The practice of using untreated wastewater is due to the tension between the growth of human settlements and the insufficient number of treatment facilities, which leaves farmers demanding water for agriculture with little choice but to resort to available water resources, whether treated or not. Use of untreated wastewater poses risks to human health as it may contain toxic chemicals, pesticides, excreta-related pathogens and other harmful residues [43]. Lack of guidelines on the treatment and use of wastewater and the lack of awareness of the risks associated with it aggravate the situation, demonstrating a gap which calls for an establishment of wastewater use standards.

In SA, the Department of Environmental Affairs (DEA) is responsible for controlling coastal area, rivers and pollution by providing citizens with an environment that is not harmful to their health or wellbeing and protecting the environment for the benefit of present and future generations. In the eThekwini-municipality, there is little guideline on safe use of greywater. Existing guidelines for wastewater use have focused mainly on the potential harmful effects of heavy metals and have not considered the potential benefits of using nutrient-rich effluent from low cost sanitation technologies for irrigation purposes. In this context wastewater refers to effluent generated from domestic waste treatment systems including greywater. According to the national sanitation policy [44] current policies do not address the policy position on greywater. There is no specific reference to greywater in the National Water Act (NWA) No. 36 of 1998 [45]. The Department of Water Affairs in terms of Section 36 of the National Water Act [45] requires that a person who irrigates with wastewater must submit to the responsible authority a completed registration form or any other information requested in writing by the responsible authority for the registration of the water use. The Department of Water Affairs and Forestry (DWAF) processes applications for any type of treated effluent re-use. However, in cases of wastewater intended for food production or sports facilities that promote probable direct contact with surfaces, the provincial Departments of Health (DOH) becomes involved [46].

\section{Methodology}

Mixed methods have been used to collect both qualitative and quantitative data to allow for data triangulation and to gain a good understanding of the complex socio-political structures and relationships, and daily realities in the settlements. Convenience sampling was applied for focus-group participants (according to availability) and in-household interviews where households were approached and asked for their participation according to availability until at least 50 households were reached in each of the three settlements.

Data was collected in three phases. The first phase in May 2017 comprised of collection of qualitative data using tools including transect walks and focus-group discussions. Community researchers facilitated the activities and acted as a bridge between the team and communities during the discussions. The next phase of data collection focused on quantitative data which was gathered through in-household surveys led by community researchers in the three low-income settlements, between February 2018 and June 2018. The questionnaires were translated into isiZulu to facilitate data collection. The purpose was to build on the observations that came from the transect walks and focus-group discussions. Finally, nine stakeholder interviews with representatives from eThekwini Municipality, Aqualima Trust, Durban City Council, Umgeni Water and experts from University of KwaZulu-Natal and University of Cape Town were conducted in June/July 2018. One of the purposes of the field work in the year of 2018 was to explore the residents' interest and knowledge of urban farming and the extent of resources (both monetary and non-monetary) required to support community-driven practices for urban farming.

\subsection{Case Studies}

This research consisted of three low-income settlement case studies in Durban, KwaZulu-Natal. The city of Durban is administered by the eThekwini municipality, and has a population of 3.8 million [47]. The three sites are introduced below. 


\subsubsection{Namibia Stop 8}

Located in the northern region of eThekwini on the outskirts of Durban, SA, Namibia Stop 8 was built in 2010-2014 by community contractors who delivered 2500 dwellings providing homes for 10000 people [48]. The process was led by the South African Alliance of community organizations and support NGOs affiliated to Shack/Slum Dwellers International (SDI) who have pioneered people-centred development initiatives by and of the poor since 1991. It includes the Community Oorganistion Resource Centre (CORC), uTshani Fund, the Federation of the Urban Poor (FEDUP), and the Informal Settlement Network (ISN). Residents had been moved there from two settlements: Namibia and Stop 8. The housing provided was a mixture of government subsidised (called RDP) of 40sqm and houses provided by FEDUP (part of the South African Slum Dwellers International Alliance) which were larger at $56 \mathrm{sqm}$. Namibia Stop 8 has water supply, a sewage system, and access to electricity through formal grid connections. Transect walks around the area showed that only few households had vegetable farms in their plots.

\subsubsection{Havelock}

Havelock is an informal settlement located $8 \mathrm{~km}$ from Durban city centre, with an estimated 200 dwellings and approximately 400 people living in the settlement [49]. The settlement sits on both private and municipality-owned land. The settlement has various hazards such as illegal electrical connections, dangerous electrical cables sprawled across paths, fire hazards and flooding. The municipality have installed ablution blocks and a detailed community enumeration was conducted in 2012 for the proposed re-blocking of the settlement. Hardly any vegetation can be seen other than bushes near the ablution block. One bush used to be a vegetable garden, but now is highly dangerous due to electrical wiring going through it. There is some gardening activity led by a couple of households despite constraints in space and the challenging topography (steep slopes). At least in one case plants are grown for traditional medicine purposes. The soil is fertile, but the illegal electrical connections pose a threat and hinder the existing efforts.

\subsubsection{Piesang River}

Piesang River is a very old low-income settlement located $25 \mathrm{~km}$ north of Durban city centre. Incrementally upgraded with formal structures in the early 1990s when a variety of building types were constructed, such as two-story flats, cottages, and single-story houses. Houses have access to water supply, sewage system and electricity. There is one large communal garden and some fruit trees spread around. The soil appears fertile, enabling a variety of trees and vegetables to be cultivated.

\subsection{In-Household Surveys}

In-household surveys were conducted by trained community researchers (each lasting approximately $20-25 \mathrm{~min}$ ) in all three settlements. A total of 153 surveys were completed collectively across the three settlements (Figure 1). The schedule of questions used has been attached (see Appendix A).

In addition to exploring the demographic profile of the participants (gender, age, occupation, income, HH size), survey questions covered farming, water and greywater use, flooding, and the presence of pests which can compromise UA activities.

Quantitative survey data was analysed using SPSS statistical software whereas qualitative elements of the survey (open-ended questions) were either coded and analysed quantitatively or analysed with the use of NVivo qualitative analysis software. Quantitative and qualitative data were triangulated to validate the results. 


\section{Survey participants}

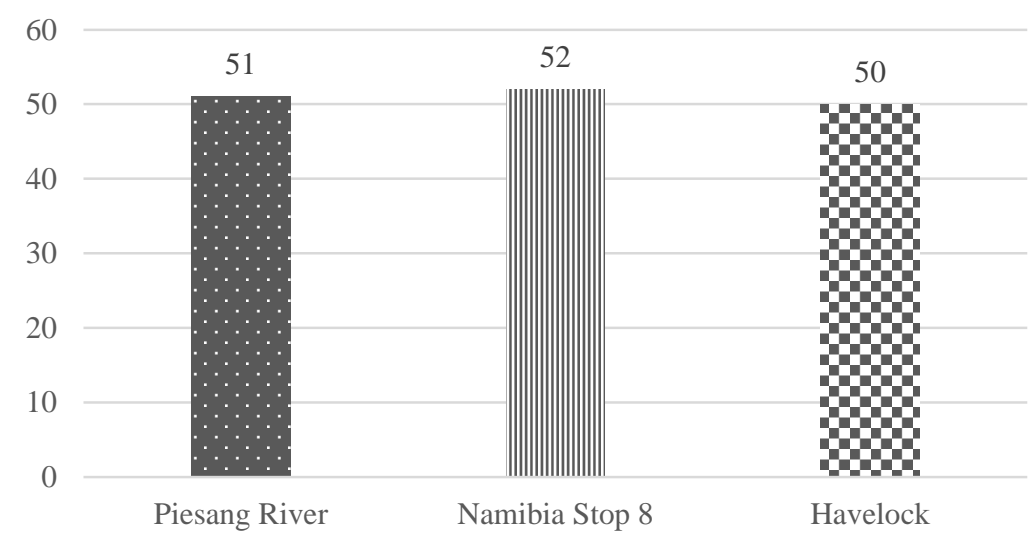

Figure 1. In-household survey participants in each of the three settlements.

\subsection{Framework}

To identify the factors impacting on the sustainability of UA, we used van den Berg's framework which draws on sustainable development factors, focusing on three dimensions: environmental, economic and social [8]. That focus is in line with what lies at the core of this study thus making the framework the most suitable from among other conceptual frameworks in the UA domain. The matrix identifies areas of synergies and conflicts under each dimension, pointing to where agricultural activities create synergies with the urban context and those where they create conflicts (Table 1). The former can be considered as opportunities and demonstrate a symbiotic relationship (e.g., in the social dimension, agriculture contributes to urban greening which is a benefit to both urban planning and urban residents), whereas the latter can be seen as challenges and present a conflicting relationship where the urban environment and agricultural activities are in direct competition for resources (e.g., land) or where one negatively impacts on the other (e.g., urban pollutants can harm agricultural crops and consequently also the consumers), thus threatening the sustainability of UA as a whole. Moreover, van den Berg's framework allows for transparent mapping out of interlinkages among the three sustainability pillars to further identify synergies and conflicts between them.

Table 1. Dimensions of sustainability of urban agriculture [8].

\begin{tabular}{|c|c|c|c|}
\hline & Environmental & Economic & Social \\
\hline Synergy/Opportunities & $\begin{array}{ll}\text { - } & \text { plant nutrients in } \\
\text { urban waste } \\
\text { and sewage; } \\
\text { - } \quad \text { health aspect in context } \\
\text { of 'urban greening' }\end{array}$ & $\begin{array}{ll}- & \text { access to inputs } \\
\text { and markets } \\
\text { - } & \text { amenity } \\
\text { - } & \text { employment and } \\
& \text { poverty alleviation }\end{array}$ & $\begin{array}{ll}\text { - } & \text { meeting human needs } \\
\text { for green (recreational) } & \text { urban space } \\
\text { - } & \text { nutritional value of } \\
\text { self-grown foods }\end{array}$ \\
\hline Conflict/Challenges & $\begin{array}{ll}\text { - } & \text { urban pollutants in } \\
\text { agricultural produce } \\
\text { - } & \begin{array}{l}\text { agrochemicals in } \\
\text { urban environment } \\
\text { - }\end{array} \\
\text { urban greening and } \\
\text { nature-borne diseases }\end{array}$ & $\begin{array}{ll}\text { - } & \text { competition from } \\
\text { urban land use systems } \\
\text { - } \quad \text { vandalism and theft }\end{array}$ & $\begin{array}{ll}\text { - } & \text { negative perceptions of } \\
\text { (peri-) urban farming }\end{array}$ \\
\hline
\end{tabular}

\section{Results}

\subsection{Quantitative Results}

Vegetable farming on one's own plot has not been reported as common, particularly in Havelock where only $14 \%$ of respondents ( $7 \mathrm{HHs}$ ) said they were growing vegetables, possibly due to space constraint. Piesang River and Namibia Stop 8 had 35\% and 33\% of respondents declare some vegetable 
farming activity, respectively. Overall, only a small proportion of HHs were involved in farming at the time of data collection. However, interest in vegetable farming was much higher, with $41 \%$ of respondents in Havelock, $44 \%$ of respondents in Piesang River and $49 \%$ of those in Namibia Stop 8 expressing interest in it and a considerable proportion of respondents declaring previous knowledge of farming: 78\% in Havelock, 67\% in Piesang River and 61\% in Namibia Stop 8 (Figure 2).

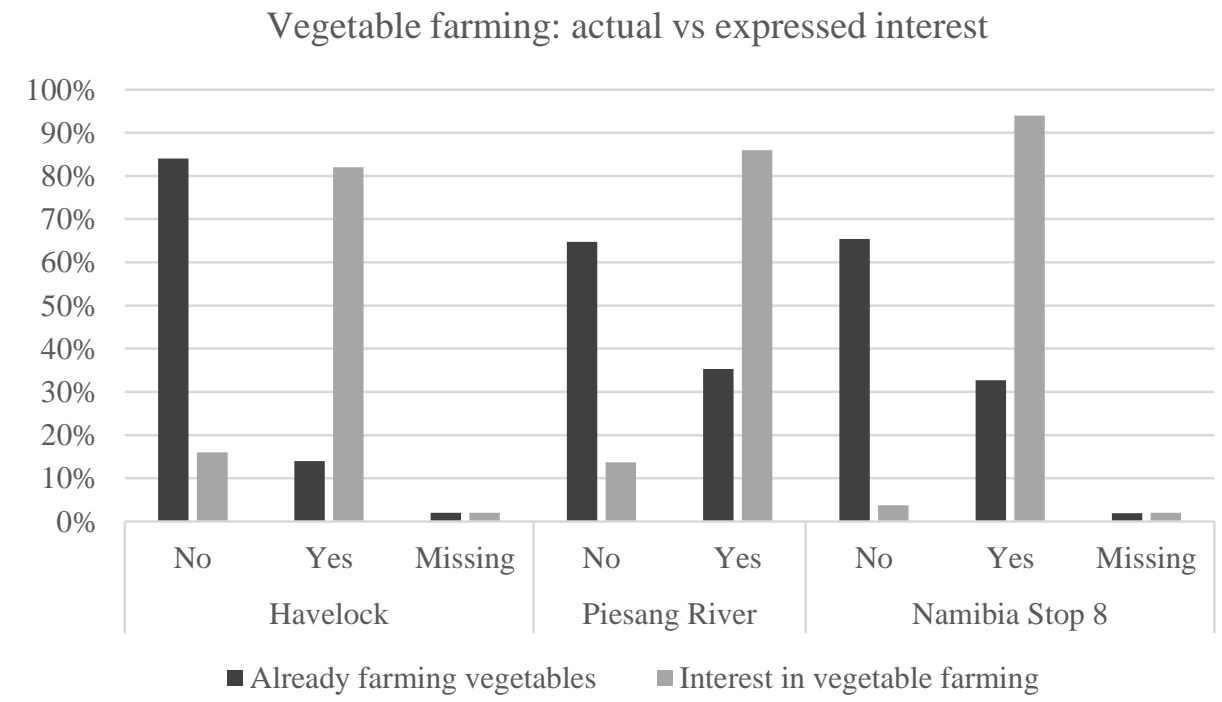

Figure 2. Percentage of households (HHs) with and without vegetable gardens in the three settlements vs those who expressed interest in vegetable farming.

Water is seen as a challenge across the three settlements and it was important to understand where the HHs would draw water from if they were to start a vegetable garden or other farming activity. Nearly $40 \%$ of Havelock respondents said the municipality tanker would be a source of water for agriculture, whereas in the other two settlements house tap was the most common choice, with $65 \%$ respondents in Piesang River and 46\% of those in Namibia Stop 8 indicating it, confirming a more reliable water supply than in Havelock. Reuse water was indicated as a potential source in Namibia Stop 8 more often than in Piesang River and Havelock, with $28 \%$ of respondents seeing it as an option (Figure 3). Another option would be water harvesting using tanks (e.g., JoJo tanks), easily installable in each dwelling. Rainwater harvesting is particularly efficient in peri-urban areas in KwaZulu-Natal where the rainfall is quite high throughout the year [50].

\section{Water for farming}

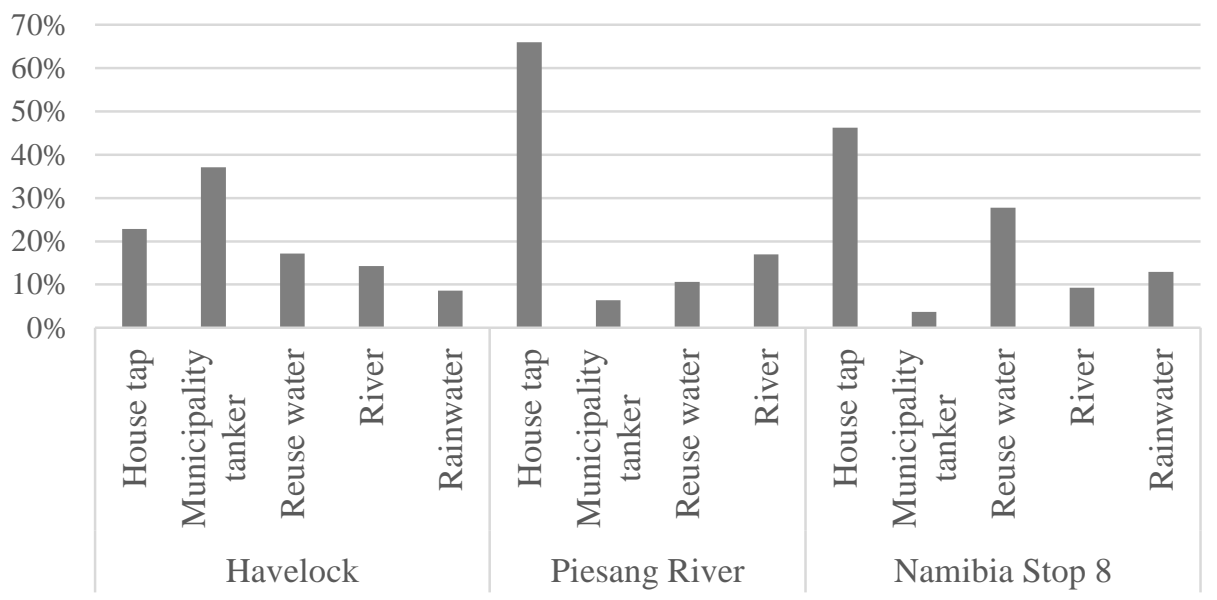

Figure 3. (Potential) sources of water for farming in the three settlements. 
The availability of water in house taps is reflected in the above figure, as well as in the fact that $96 \%$ of Havelock respondents said they fetch water outside of the house, whereas only $8 \%$ of Piesang River respondents and $4 \%$ of Namibia Stop 8 respondents said they do so. In Havelock, water is fetched from the municipal tap once or twice a day and usually everyone in the $\mathrm{HH}$ is responsible for fetching it, depending on who is at home and available.

Disposal of used water varies across the settlements. In Havelock, the stream is the most common way of disposing of it which also causes issues such as water pollution and blockages. In Piesang River, it is the drain that is used to that end and in Namibia Stop 8 the range of practices is wider, with the plot outside of the house, a vegetable garden and toilet/showers being the most common ways, as reported by respondents (Figure 4).

\section{Disposal of used water}

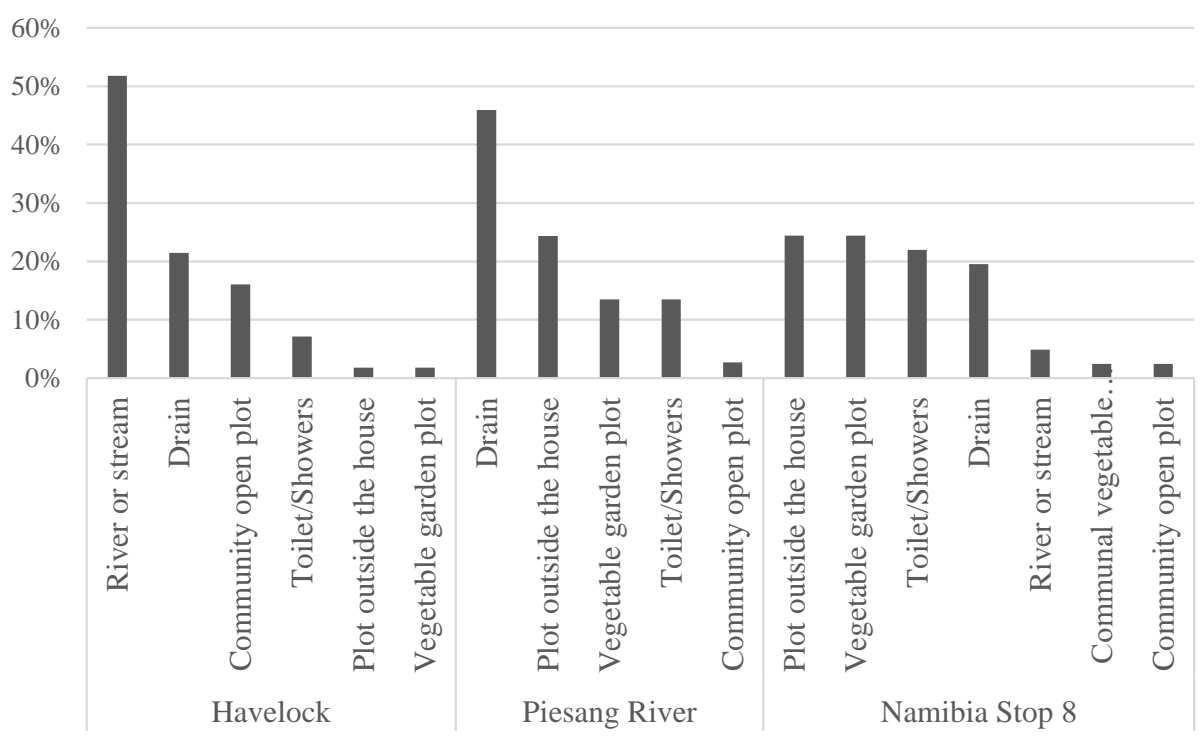

Figure 4. Disposal of used water in the three settlements.

Despite some previous knowledge of farming among respondents in all three settlements, majority of respondents in each one of them said they would be interested in attending farming workshops if they were made available to them (Figure 5). In Havelock, as many as $94 \%$ of respondents expressed interest. Attending such training programmes once a week or even a few times a week, were the preferred frequencies for the respondents, as dictated by their schedules.

Interest in participating in farming workshops

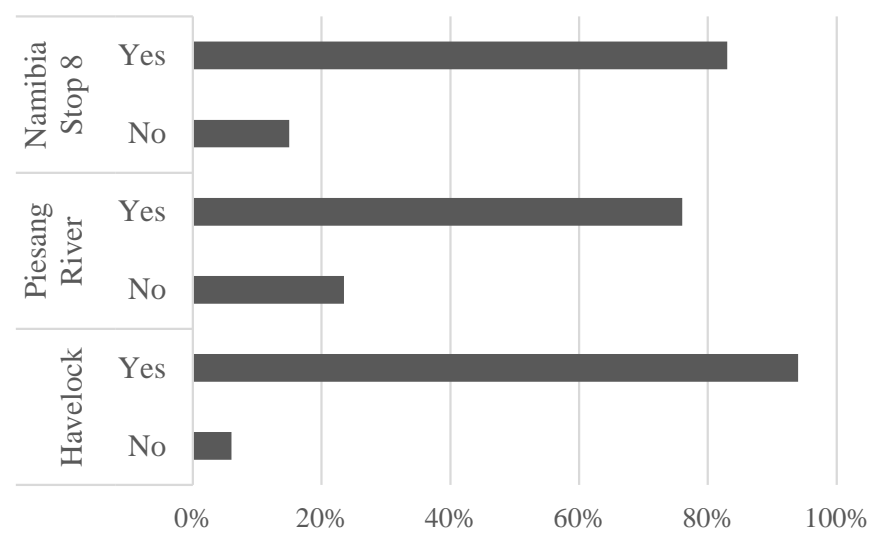

Figure 5. Interest in participating in farming training among respondents in Havelock, Piesang River and Namibia Stop 8. 
For those employed and with regular working hours, the suggested training would be fewer hours per week than for those without regular occupations and more free time during the day. It was noted that particularly elder women had a strong interest in urban farming initiatives.

In Havelock, the most desirable support for agriculture were seeds, manure and training; in Piesang River: seeds, manure and free water; whereas in Namibia Stop 8 seeds, free water and training, as shown in Figure 6 below.

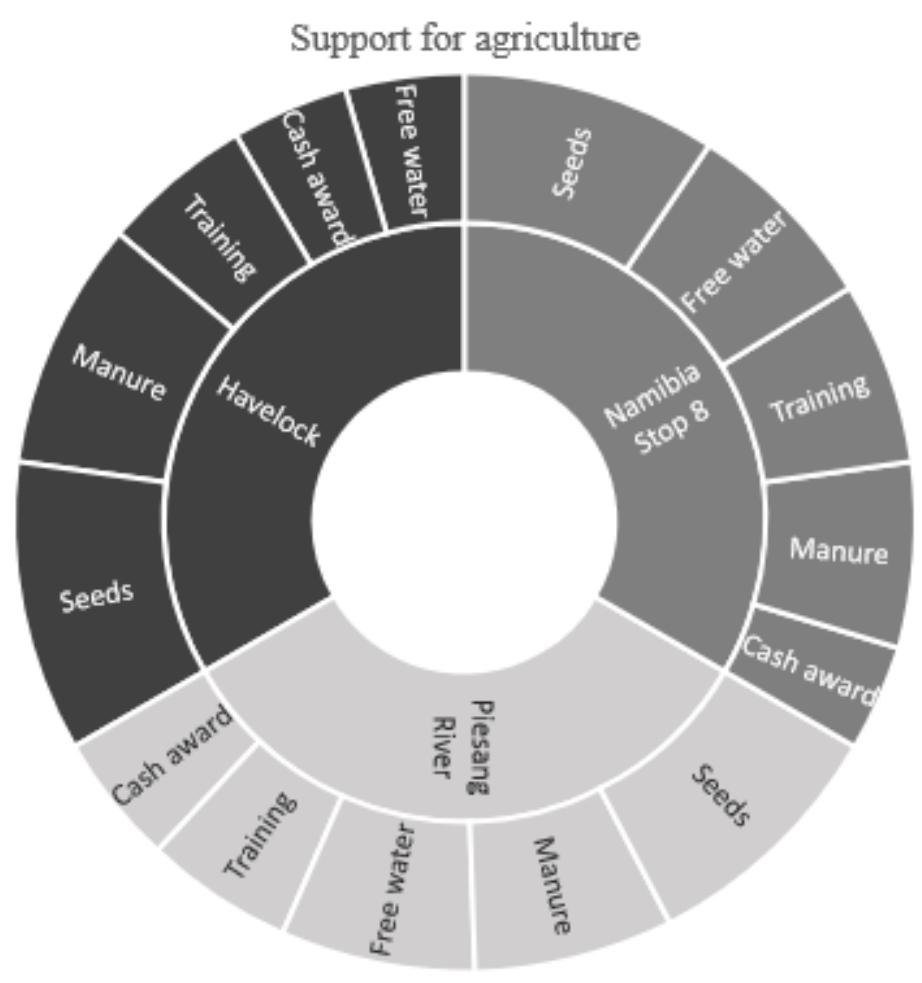

Figure 6. Most useful support for agriculture as indicated by survey respondents.

Free water was the least important kind of support expressed by the respondents in Havelock where households do not have access to water in their homes but rather draw water from the communal water points. Whereas in Piesang River and in Namibia Stop 8 free water was among the top three most important ways in which they would like to receive support for agricultural activities. As water from one's own supply would have to be paid for, the heavy required usage would mean high water bills. On the contrary, water drawn from communal outlets in Havelock is free and hence that need has not been prioritised by the respondents.

As pests can be a problem in informal settlements and can have an impact on the viability of agricultural activities, respondents were asked whether pests were an issue in their respective settlements and houses. Overall, pests were reported to be a problem in $60 \%$ of $\mathrm{HHs}$ in Havelock, $82 \%$ of HHs in Piesang River and 85\% of HHs in Namibia Stop 8, suggesting a relatively important challenge which could impact on urban farming activities, and the need to address it for the preservation of crops and to avoid losses.

\subsection{Qualitative Results}

Results from the gathered qualitative data (focus groups, transect walk and household interviews) for each of the three settlements are demonstrated in Table 2 below. A brief background of the history of farming (if any) and current agricultural activities is provided, followed by currently cultivated crops, existing skills and need for additional training, water use, and key challenges as expressed by the participants. 
Table 2. Urban agriculture (UA) activities, conditions and challenges in each of the three settlements.

\begin{tabular}{|c|c|c|}
\hline Havelock & Piesang River & Namibia Stop 8 \\
\hline $\begin{array}{l}\text { Current situation: } \\
\text { Little to no current farming activities; } \\
\text { some traditional medicine plant } \\
\text { growing; a co-operative in the past but } \\
\text { no longer active; high interest in } \\
\text { farming (mainly for own use instead } \\
\text { of buying produce, and for selling). }\end{array}$ & $\begin{array}{l}\text { Current situation: } \\
\text { Individual and co-operative farming } \\
\text { active in the settlement; municipal } \\
\text { corporation provided land, } \\
\text { households' (HHs) allocated plots; no } \\
\text { committee managing the co-op; } 2 \\
\text { large farms: one managed by co-op, } \\
\text { the other one by individuals; high } \\
\text { interest in farming. }\end{array}$ & $\begin{array}{l}\text { Current situation: } \\
\text { Backyards used to grow vegetables } \\
\text { among approx. half of participants; } \\
\text { high interest in farming. }\end{array}$ \\
\hline $\begin{array}{l}\text { Interest in farming: Yes-stronger } \\
\text { interest from women groups }\end{array}$ & $\begin{array}{l}\text { Interest in farming: Yes-stronger } \\
\text { interest from elder women }\end{array}$ & $\begin{array}{l}\text { Interest in farming: Yes-stronger } \\
\text { interest from elder women }\end{array}$ \\
\hline $\begin{array}{l}\text { Current crops: some individual } \\
\text { fruit trees. }\end{array}$ & $\begin{array}{l}\text { Current crops: different vegetables } \\
\text { and fruit trees. }\end{array}$ & Current crops: different vegetables. \\
\hline $\begin{array}{l}\text { Skills \& training: some residents have } \\
\text { farming certificates; interest in } \\
\text { learning more about farming. }\end{array}$ & $\begin{array}{l}\text { Skills and training: very good } \\
\text { knowledge of vegetable growing; no } \\
\text { expressed need for more training. }\end{array}$ & $\begin{array}{l}\text { Skills and training: good knowledge } \\
\text { of vegetable growing; interest in } \\
\text { learning more about farming. }\end{array}$ \\
\hline $\begin{array}{l}\text { Water use: unable to use water from } \\
\text { stream due to contamination- } \\
\text { environmental threat; water from } \\
\text { ablution blocks. }\end{array}$ & $\begin{array}{l}\text { Water use: tank water used (often } \\
\text { empty); river water (poor quality). }\end{array}$ & $\begin{array}{l}\text { Water use: tank water used; greywater } \\
\text { occasionally used to water plants + } \\
\text { greywater reuse project underway; } \\
\text { nearby stream (low water level). }\end{array}$ \\
\hline $\begin{array}{l}\text { Challenges: lack of adequate } \\
\text { land/space; potentially available land } \\
\text { close to sewer line; quality of the soil; } \\
\text { sufficient water supplies. }\end{array}$ & $\begin{array}{l}\text { Challenges: pollution of the river front } \\
\text { which used to be used for vegetable } \\
\text { growing; poor water quality from the } \\
\text { river \& sufficient water supplies. }\end{array}$ & $\begin{array}{l}\text { Challenges: fencing for gardens and } \\
\text { area used for farming near the stream } \\
\text { to protect crops; sufficient } \\
\text { water supplies. }\end{array}$ \\
\hline
\end{tabular}

Qualitative findings indicated a strong interest in UA in the three case studies, hindered by different factors. Across all three settlements, women are the most engaged group to date and the one with highest aspirations for participating in farming activities, whether on an individual or community basis. The oldest settlement, Piesang River, was observed to be the most proactive and organised settlement in regard to UA, with some municipal support and cooperatives in place, making the UA governance structures much more advanced than in Namibia Stop 8 and Havelock, where UA efforts have been limited mainly to individual or ungoverned group farming activities. As revealed in focus group discussions, community mobilisation is among the key drivers of successful implementation and management of initiatives such as UA. Strong community leadership (especially female leadership) and higher levels of social cohesion in Piesang River, have resulted in continued UA efforts, including the ability to gain and share knowledge on best farming practices, thus producing more diverse crops across both community and individual farms.

The diversity of crops has been found to be dependent on the existing knowledge of UA among the residents, as well as the availability of seeds, which was expressed as one of the top needs in all three settlements. Close ties to the settlement residents' rural homes, particularly in the case of Havelock, are reflected in plants grown for traditional medicine practices, which are common in rural areas across SA. Additionally, availability of water was reported by study participants as an important challenge, not only for farming but also for daily use. Poor quality of water from the local streams or rivers and lack of reliable water supply to the settlements by the utilities means that residents are hesitant to use those resources for farming, first prioritising whatever water supply they have access to for household needs. The question of the use of greywater is under consideration in Namibia Stop 8, however, varied perceptions (including negative) of the suitability of greywater for agriculture and lack of awareness of the opportunities greywater reuse can bring, means that further education among community members will be required to ensure buy in and best practices.

Lastly, lack of available land and poor soil quality, particularly in Havelock, as well as lack of fencing around vegetable gardens and farming plots, were observed during transect walks as significant barriers to boosting UA efforts in the study sites. This was further confirmed in focus 
group discussions were some of the participants expressed their concerns about issues related to land availability, including ownership.

\section{Discussion}

Agriculture has become a major influence in sustaining the livelihoods and providing food security amongst the middle- and lower-income households [51,52]. The growing population within the urban and peri-urban areas is becoming more dependent on agriculture as a means of survival and nutritional bearer in their communities, as well as a solution to food security. Despite the overall high interest in fruit and vegetable farming within each of the three settlements, and some pre-existing skills and agricultural activities, there remain several challenges the residents are faced with to either continue or commence farming. From a socio-environmental perspective, space (i.e. availability of land), poor quality of available water supplies and sufficiency of the required water supplies, as well as soil quality and availability of farming tools, all demand attention if UA is going to develop or expand in each of the sites.

Even though the eThekwini municipality has previously had initiatives to promote urban farming in low-income areas for self-reliance (mainly for socio-economic impact purposes associated with food availability and livelihood creation), there has been a lack of developed guidelines and plans for execution, which has translated into a limited capacity of the informal settlement dwellers to successfully carry out urban farming projects locally, including within their own compounds, thus hindering opportunities for yielding benefits.

There have been initiatives led by eThekwini municipality where communal vegetable gardens have been set up and funded but subsequently not maintained by the dwellers. One example is an eThekwini project in Joanna Road where they installed urban gardens and a creche. The municipality levelled the ground, provided topsoil, seeds and trained community members for a month. Initially, community members expressed a high level of interest and were keen to participate but after a while they felt it was too much effort and stopped managing the gardens. Self-organisation of the community and garden management proved to be among the biggest challenges and alternative models should be sought, including a potential business franchise model. Even though those interventions were developed in consultation with the dwellers, they failed to capitalise on the social networks and groups such as elder women who have the relevant skill sets and motivation to engage in UA.

Table 3 below summarises areas of synergies and conflicts for scaling-up localised community-driven solutions for UA in the three case studies in Durban. The table was obtained by applying van den Berg's framework to the research findings and reviewing the current existing UA projects in eThekwini metropolitan area, including the best and worst practices.

It is evident that promoting urban farming in low-income communities can foster livelihood creation and feed residents in highly dense urban settings which fulfils both the municipality's and the communities' aspirations. However, there is a need to develop a community-led approach if such initiatives are expected to be sustainable and create socio-economic impacts while preserving the environment. As was discovered in Piesang River-the most ancient and organised of the three settlements in regard to UA management, encouraging and facilitating community self-organisation and leadership (particularly women leadership) could have the potential to boost such initiatives, making a long-term impact on the communities involved. Cropping patterns, tilling techniques and dryland farming techniques, which can reduce water use to avoid theft or over consumption of scarce water resources, proved to be useful tools which should be considered and should be accompanied with adequate training on how and when to use them. The provision of training supporting programmes on urban farming will also play a critical role, giving settlement inhabitants the know-how of best practices and most feasible crops given the local conditions (such as soil, precipitation etc.). Other than in Piesang River, where the knowledge of farming techniques was reported as very good by study participants, the need for more training on UA was clearly expressed in the other two settlements, revealing it as a critical component for the community to be able to lead on UA efforts. Recognition of 
traditional practices, such as traditional medicine, might additionally help boost interest and inform design of appropriate UA activities.

Table 3. Dimensions of sustainability (van den Berg's framework) of UA in the three study sites.

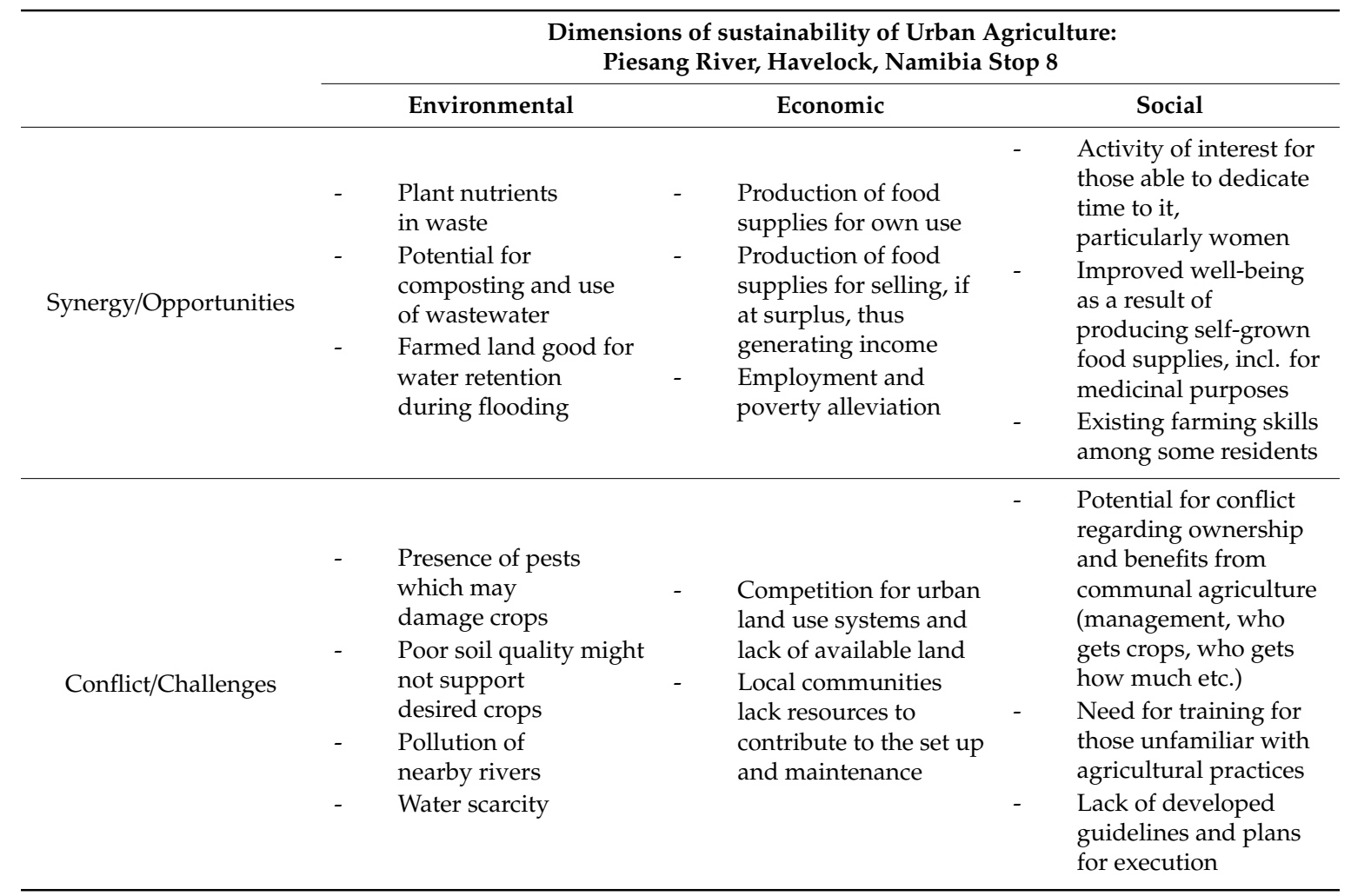

The potential for reuse of greywater, and the acceptability of such uses, need to be explored as greywater is disposed in open plots and streams, as has been discovered in Havelock and Piesang River. There is a tension between promoting socio-economic activities which increase water scarcity in low-income settlements whilst they are also considered environmentally and socially risky in water scarce sites, especially with the most recent water resource shortages in SA (D-Day) affecting millions of citizens. Underlying infrastructural and environmental challenges causing a frequent lack of water access, therefore, put under question the prioritisation of farming activities as other more critical needs (e.g., washing, flushing) would have to be compromised, unless alternatives were found.

While water issues, including water scarcity, lie at the centre of implementing sustainable urban farming activities in informal settlements, land and the lack of space also require a careful consideration, as despite the high interest in getting involved in farming, space can be another key constraint. Fieldwork showed that space availability is a significant limitation, particularly in informal settlements (like Havelock) which lack sufficient space for community facilities and basic infrastructure, additionally restraining UA opportunities. Our work also demonstrates the crucial role of women and their strong engagement in UA not just for subsistence but also for livelihood creation and socio-economic empowerment. The strongest interest in UA was expressed by women in all three settlements who were also the ones most engaged in any pre-existing activities. However, there is a problem with policy implementation on the ground, especially when it comes to accommodating women in agriculture at subsistence and commercial levels. Thus, the UN-Women Regional Director for Eastern and Southern Africa, Christine Musisi, formally challenged governments and financial institutions in the region to prioritize support for female farmers through policies, funding and programming in 2014, which-she said-would be an investment that will assist the growth rate of food security, especially in rural area [53]. In fact, according to the State of Food and Agriculture by the 
Food and Agriculture Organization [54] (p.6) “[ ... ] women's roles in agriculture vary across regions but, everywhere, women face gender-specific constraints that reduce their productivity and limit their contributions to agricultural production, economic growth and the well-being of their families, communities and countries".

Further engagement with women groups and capacity building could pave the path for participatory UA interventions in low-income settlements and contribute to the enhancement of food security, personal well-being of women and other community members and the unlocking of women's potential through upskilling and leadership, thus boosting socio-economic impact of UA interventions. However, these should be designed with caution so as not to increase environmental pressures on the selected sites and communities, and with a recognition of the diverse range of synergies and conflicts between environmental, economic and social dimensions of UA, some of which have been mapped out in this study.

\section{Conclusions and Recommendations}

This paper explored challenges and opportunities for sustainable urban farming as an integrated environmental management strategy for the upgrading of informal settlements in SA. By applying mixed methods and action research approaches, this study collected community perceptions around the implementation of UA and assessed the three sustainability dimensions of UA proposed by van den Berg's framework. The use of mixed methods enabled the authors to assess the coverage of urban farming activities through quantitative evidence and understand key barriers and opportunities through qualitative evidence. Future work could include conducting this study in other cities in SA to further inform policy makers on key enablers for urban farming and collecting evidence on the viability of water-saving measures, such as reuse of greywater, which can prove critical based on our findings.

There is a strong interest in participation in UA in urban dense low-income settings both for subsistence and livelihood creation. Elder women expressed stronger interest and willingness to invest time in creating vegetable gardens either in their house plots or communal plots. Thus, consultations with women should be a standard practice in developing UA policies and interventions. The key barriers for scaling up were socio-environmental in nature: access to water resources, capacity building on water-efficient irrigation techniques, availability of suitable land, and community self-organisation. Lack of security of tenure among the residents further exacerbates those barriers and stifles their motivation to invest in UA. Our study demonstrates the need to support community-driven processes and sustain investment (time, resources, training) for maintenance in order to ensure sustainability and balanced development of UA initiatives. Upgrading programmes should take community needs and existing skills into consideration and develop spaces that can accommodate UA and associated activities to boost socio-economic opportunities while avoiding undesirable environmental consequences. Policy makers need to create an enabling environment for academics, NGOs and the private sector to co-develop water efficient solutions to manage the food-water nexus and capitalise on localised community structures and groups such as co-operatives and women groups. In addition, further research should focus on developing integrated socio-economic, environmental and technical tools to guide the implementation of UA, such as specific guidelines and training programmes to support women seeking to turn urban agricultural activities into real livelihood opportunities while implementing food and water security strategies.

Author Contributions: Conceptualization, P.P. and I.B.; methodology, P.P. and I.B.; software, I.B.; validation, P.P., and C.L.; formal analysis, I.B.; investigation, P.P. and C.L.; writing—original draft preparation, I.B.; writing-review and editing, P.P. and C.L.; funding acquisition, P.P. and C.L.

Funding: This study was funded by the Royal Society Travel Grant, a Royal Society Newton Advanced Fellowship (ref. NA150082) and an Economic and Social Research Council (ESRC) award as part of the Newton Fund, in collaboration with the National Research Foundation (NRF) in South Africa (www.isulabantu.org).

Acknowledgments: The project is led jointly by the University of Westminster (UK), the University of KwaZulu-Natal (SA), the University College London (UK), a non-governmental organization (NGO) uTshani Fund (SA), and the eThekwini Municipality (SA). The authors would like to thank the ISULabaNtu project team, the officers of uTshani Fund and particularly Jeff Thomas for his precious assistance and support; Bashintshile 
(Sibongile) Buthelezi and Duduzile (MaDudu) Khumalo from the University of KwaZulu-Natal, community researchers from Namibia Stop 8, Piesang River and Havelock communities as well as UKZN Master students for providing support with data collection and translation during fieldwork in Durban. The authors would like to thank Maria Christina Georgiadou, Chris Buckley, Catherine Sunderland, Alfred Odindo, Judith T Ojo-Aromokudu (UKZN), Sharon Migeri and Olivia Fokeerah for their support during fieldwork and contributions to this publication.

Conflicts of Interest: The authors declare that they have no conflict of interest.

\section{Appendix A In-Household Survey Schedule}

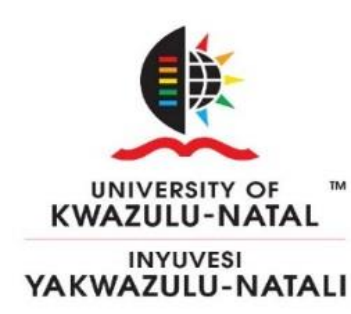

PRE-QUESTIONNAIRE

1. Name of household head?

2. If you are not the household head your name?

3. What is your age and gender?

4. What education have you completed?
a. Primary
b. Secondary
c. Tertiary
d. Other (what education?)

5. How many adults and children (below the age of 16) live in the household including you?

6. What is your occupation?

7. Do you work in any other job? If so, what?

8. Is your house rental or owned?

9. What is your average monthly income?

\begin{tabular}{|l|l|}
\hline$<\mathrm{R} 1000$ & \\
\hline R1001-R1500 & \\
\hline R1501-R2000 & \\
\hline R2001-R3000 & \\
\hline R3001-R4000 & \\
\hline
\end{tabular}
UNIVERSITYOF
WESTMINSTER

\section{WESTMINSTER ${ }^{\text {卌 }}$}




\begin{tabular}{|l|l|}
\hline R4001-R5000 & \\
\hline R5001-R6000 & \\
\hline R6001-R7000 & \\
\hline R7001-R8000 & \\
\hline R8001-R9000 & \\
\hline R9001-R10000 & \\
\hline R10000 + & \\
\hline
\end{tabular}

10. Do you have any other assets, such as tv/car/motorbike/fridge/computer?

11. How well connected do you feel within the community?
a. Not connected at all
b. Somewhat connected
c. Connected
d. Very connected

\section{SOLID WASTE MANAGEMENT}

12. Is solid waste being collected?
a. Yes
b. No

13. How frequently is solid water/garbage collected?
a. Daily
b. Once a week
c. Once every two weeks
d. Never
e. Other

14. Are you satisfied with the service?
a. Yes
b. No

15. If not satisfied why? (List reasons)

16. Where does the waste go if it is not collected?
a. Street outside house
b. open plot near house
c. river/stream
d. Bins
e. Plastic bag outside house
f. other

17. Is the waste segregated within your community?
a. Yes
b. No 
18. If above is yes, where?
a. House
b. Communal plot
c. Other

19. Do you recycle?
a. Yes
b. No

20. If above is yes, list what items you recycle?

21. Do you get help from the municipality for recycling for the following:
a. Recycling plot
b. Training
c. Financial support
d. Collection of recycling
e. Other

\section{FLOODING}

22. Does it flood outside your house?
a. Yes
b. No

23. List which months it floods outside your house

24. How are you affected by the flooding?
a. Transport elsewhere is difficult
b. Going to work is affected
c. Less income
d. Time wasted on cleaning
e. Doing daily activities
f. Using toilets
g. Children cannot go to schools
h. Power cut
i. Damage to house
j. Other

25. How much money is spent on average during/after flooding to repair housing as a result of damage due to rains?

Rand

26. How much working time is lost due to floods? 


\section{FARMING}

27. Do you have a vegetable garden in your plot outside your house?
a. Yes
b. $\quad \mathrm{No}$

28. Are you interested in vegetable farming?
a. Yes
b. No

29. If above is yes, list the names of vegetables/plants that you would grow

30. Where would you get the water from for watering the vegetables/plants
a. Your house tap
b. Tanker from municipality
c. Reuse water from washing clothes/bath/cooking
d. Other

31. Do you have any previous knowledge of farming or the seasonality of plants?
a. Yes
b. No

32. How much time would you invest in a vegetable plot?

mins/day

33. How much would you be willing to invest in watering a vegetable plot?

Rands

34. Would you be willing to participate in community-led farming workshops if they were available for you?
a. Yes
b. No

35. How often would you attend such workshops?
a. Once a week
b. Once a month
c. Other

36. What type of support do you expect from the municipality for vegetable farming?
a. Free water
b. Seeds
c. Manure
d. Training
e. Cash award
f. Other 
37. Are rats or other pests a problem for you?
a. Yes
b. No

\section{WATER USE}

38. Do you get water through taps in your house?
a. Yes
b. No

39. If above is No answer the following:
a. Do you have to fetch water from elsewhere? (Yes/No)
b. How far away? (Distance in _____meters)
c. How often do you fetch water daily? (Once, twice, other
d. Who is responsible for fetching the water? (Women, man, girl child, boy child)

40. Where do you throw your used water?
a. In plot outside house
b. Vegetable garden in yard
c. Communal vegetable garden plot
d. Community open plot
e. River/stream
f. Other

\section{SANITATION}

41. Do you have a private toilet which you use?
a. Yes
b. No

42. If above is yes is it a flush toilet
a. Yes
b. No

43. If your house has a private flush toilet list the advantages

44. If your house has a private flush toilet, list the disadvantages

45. Do you use public toilets?
a. Yes
b. No

46. If you use public toilets, what are the advantages?
a. Clean
b. Good servicing 

c. Safe to use
d. Cheap/Free
e. Chance to meet people socially
f. Easy walk to toilets
g. Can go with family and friends
h. Other

47. If you use public toilets, what are the disadvantages?
a. Not clean
b. Not safe to use
c. Expensive
d. Difficult to walk to the toilets
e. Flooded in rains
f. Does not work
g. Lack of privacy
h. Long queue
i. No water in toilets
j. Other:

48. What are the challenges you face around sanitation?
a. Safety
b. Cleanliness
c. Are they serviced?
d. Ease of use

\section{ELECTRICITY}

49. Do you have access to electricity in your house?
a. Yes
b. No

50. How much do you pay per month?

Rands

51. Are there any problems with electricity?
a. Access not in house
b. Connection charges high
c. Bill is very high
d. Do not understand billing system
e. Power cuts
f. Power supply not reliable with surges damaging appliances
g. Not safe in rainy season
h. Other

52. What electric devices do you have?
a. Radio
b. Television 

c. Mobile Phone
d. Lamps
e. Heater
f. Other

53. Who is responsible for paying bills in the household?

\section{References}

1. UN Department of Economic and Social Affairs (DESA), Population Division. The World's Cities in 2016-Data Booklet (ST/ESA/SER.A/392); UNDESA: New York, NY, USA, 2016.

2. UN-Habitat. State of African Cities 2014: Re-Imagining Sustainable Urban Transitions. HS/004/14E. 2014. Available online: https://unhabitat.org/books/state-of-african-cities-2014-re-imagining-sustainable-urbantransitions/\# (accessed on 14 June 2019).

3. UN-Habitat. State of the World's Cities 2012/2013: Prosperity of Cities; Routledge: New York, NY, USA, 2013; Available online: https://sustainabledevelopment.un.org/content/documents/745habitat.pdf (accessed on 14 March 2019).

4. Wolpe, P.; Reddy, Y. Alleviating urban energy poverty in the informal sector: The role for local government. Presented at Inequality and Structural Poverty in South Africa: Towards Inclusive Growth and Development, Johannesburg, South Africa, 20 September 2010. Available online: http://www.cityenergy.org.za/uploads/ resource_85.pdf (accessed on 14 June 2019).

5. Socio-Economic Rights Institute (SERI) of South Africa. Informal Settlements and Human Rights in South Africa. 2018. Available online: https://www.ohchr.org/Documents/Issues/Housing/InformalSettlements/SERI. pdf (accessed on 14 June 2019).

6. Kekana, D.S. A Socio-Economic Analysis of Urban Agriculture: The Soshanguve Project Case Study. Master's Thesis, University of Pretoria, Pretoria, South Africa, 2006. Available online: https://repository.up.ac.za/ bitstream/handle/2263/27581/dissertation.pdf?sequence $=1$ (accessed on 14 June 2019).

7. Van Averbeke, W. Urban farming in the informal settlements of Atteridgeville, Pretoria, South Africa. Water SA 2007, 33, 337-342. [CrossRef]

8. Van den Berg, L. Peri urban agriculture and urban planning. In Proceedings of the Paper for the CGIAR SIUPA Action Plan Development Workshop South East Asia Pilot Site, Hanoi, Vietnam, 6-9 June 2000.

9. Dovey, K.; King, R. Forms of informality: Morphology and visibility of informal settlements. Built Environ. 2011, 37, 11-29. [CrossRef]

10. Huchzermeyer, M. Cities with 'Slums': From Informal Settlement Eradication to a Right to the City in Africa; UCT Press: Claremont, CA, USA, 2011.

11. Roy, A. Slumdog Cities: Rethinking Subaltern Urbanism. Int. J. Urban Reg. Res. 2011, 35, 223-238. [CrossRef] [PubMed]

12. Statistics South Africa (Stats SA). National Poverty Lines 2018. 2018. Available online: http://www.statssa. gov.za/publications/P03101/P031012018.pdf (accessed on 14 June 2019).

13. Republic of South Africa, RSA. The White Paper on Reconstruction and Development. 1994. Available online: https://www.gov.za/sites/default/files/governmentgazetteid16085.pdf (accessed on 14 June 2019).

14. Kovacic, Z. Governing informality through representation: Examples form slum policies in Brazil and South Africa. Cities 2018. [CrossRef]

15. Huchzermeyer, M. The New Instrument for Upgrading Informal Settlements in South Africa: Contributions and Constraints. In Informal Settlements: A Perpetual Challenges? Huchzermeyer, M., Karam, A., Eds.; University of Cape Town Press: Cape Town, South Africa, 2006.

16. Khan, F.; Thring, P. Housing Policy and Practice in Post-Apartheid South Africa; Heinemann: Johannesburg, South Africa, 2003.

17. Tissington, K. A resource guide to housing in South Africa 1994-2010. In Legislation, Policy, Programmes and Practice; Socio-Economic Rights Institute of South Africa (SERI): Johannesburg, South Africa, 2011.

18. UNDP. Urban Agriculture: Food, Jobs and Sustainable Cities. In United Nations Development Program, Publication Series for Habitat II; UNDP: New York, NY, USA, 1996. 
19. Rogerson, C. Urban agriculture and urban poverty alleviation: South African debates. Agrekon 1998, 37, 171-188. [CrossRef]

20. Zeunert, J.; Waterman, T. Routledge Handbook of Landscape and Food; Routledge: London, UK, 2018.

21. Ackerman, K.; Conard, M.; Cullingan, P.; Plunz, R.; Sutto, M.P.; Whittinghill, L. Sustainable Food Systems for Future Cities: The Potential of Urban Agriculture. Econ. Soc. Rev. 2014, 45, 189-206.

22. Stewart, R.; Korth, M.; Langer, L.; Rafferty, S.; Rebelo da Silva, N.; van Rooyen, C. What are the impacts of urban agriculture programs on food security in low and middle-income countries? Environ. Evid. 2014, 2, 1-10. [CrossRef]

23. Kumar, S.; Reddy, V.; Mandla, V.R.; Sudha, M.C.; Shanawaz, S.M. Integrated Water and Wastewater Management for A Township. J. Ind. Pollut. Control 2015. Available online: http://www.icontrolpollution. com/articles/integrated-water-and-waste-water-management-for-a-township-.php?aid=65714) (accessed on 14 June 2019).

24. Mougeot, L.J. AGROPOLIS: The Social, Political and Environmental Dimensions of Urban Agriculture; Earthscan: London, UK, 2005.

25. Richter, J.; Schnitzler, W.H.; Gura, S. (Eds.) Vegetable production in peri-urban areas in the tropics and subtropics-food, income and quality of life. In German Foundation for International Development; Food and Agriculture Development Centre: Feldafing, Germany, 1995.

26. Game, I.; Primus, R. Urban Agriculture. GSDR 2015 Brief, State University of New York College of Forestry and Environmental Science. 2015. Available online: https://sustainabledevelopment.un.org/content/ documents/5764Urban\%20Agriculture.pdf (accessed on 14 June 2019).

27. Mougeot, L.J. Urban Agriculture: Definition, Presence, Potentials and Risks, and Policy Challenges; Cities Feeding People Series Report 31; International Development Research Centre (IDRC): Ottawa, ON, Canada, 2000.

28. UN-Habitat. Urban Patterns for a Green Economy (Four Series); UN-Habitat: Nairobi, Kenya, 2012; Available online: https://unhabitat.org/series/urban-patterns-for-a-green-economy/ (accessed on 14 March 2019).

29. Jabeen, H.; Johnson, C.; Allen, A. Built-in resilience: Learning from grassroots coping strategies for climate variability. Environ. Urban. 2010, 22, 415-431. [CrossRef]

30. Olivier, D.W.; Heinecken, L. Beyond food security: Women's experiences of urban agriculture in Cape Town. Agric. Hum. Values 2017, 34, 743-755. [CrossRef]

31. World Bank. Urban Agriculture: Findings from Four City Case Studies. In Urban Development Series Knowledge Papers; World Bank: Washington, DC, USA, 2013; pp. 1-104.

32. Mansfield, B.; Brillembourg, A.; Klumpner, H. Urban Agriculture Systems-Transforming the Lives of People in Informal Settlements. Global Compact Cities Programme. 2015. Available online: http://citiesprogramme. org/wp-content/uploads/2016/03/Case-Study-Cape-Town-Urban-Agriculture.pdf (accessed on 14 June 2019).

33. Frayne, B.; Battersby-Lennard, J.; Fincham, R.; Haysom, G. Urban food security in South Africa: Case study of Cape Town, Msunduzi and Johannesburg. In Development Planning Division Working Paper Series No. 15; DBSA: Midrand, South Africa, 2019.

34. Donnenfeld, Z.; Crookes, C.; Hedden, S. A delicate balance: Water scarcity in South Africa. Southern Africa Report 13; Institute for Security Studies and Water Research Commission. 2018. Available online: https://issafrica.s3.amazonaws.com/site/uploads/sar13-2.pdf (accessed on 14 June 2019).

35. Bakare, B.F.; Mitsweni, S.; Rathilal, S. A pilot study into public attitudes and perceptions towards greywater reuse in a low-cost housing development in Durban, South Africa. J. Water Reuse Desalin. 2016, 6, 345-354. [CrossRef]

36. Rodda, N.; Carden, K.; Armitage, N.; du Plessis, H.M. Development of guidance for sustainable irrigation use of greywater in gardens and small-scale agriculture in South Africa. Water SA 2011, 37, 727-738. [CrossRef]

37. Bakare, B.F.; Mitsweni, S.; Rathilal, S. Characteristics of greywater from different sources within households in a community in Durban, South Africa. J. Water Reuse Desalin. 2017, 7, 520-528. [CrossRef]

38. eThekwini Municipality. Drought Mitigation Actions in eThekwini. Fact Sheet 8. 2016. Available online: http://prg.ukzn.ac.za/docs/default-source/projects/fact-sheet-8_drought-mitigation.pdf?sfvrsn=2 (accessed on 14 June 2019).

39. eThekwini Municipality. Agro Ecology Unit. 2011. Available online: http://www.durban.gov.za/City_ Services/AgroEcology/Pages/Agro-Ecology-Background.aspx (accessed on 14 June 2019). 
40. Pollution Research Group University of KwaZulu-Natal (PRG UKZN). The Newlands Mashu Research Site. 2015. Available online: http://prg.ukzn.ac.za/docs/default-source/supporting-documentation/newlandsbrochure-final-lr.pdf?sfvrsn=2 (accessed on 14 June 2019).

41. EAWAG (n/d). The Newlands Mashu Research Site. Available online: https://www.eawag.ch/fileadmin/ Domain1/Abteilungen/eng/projekte/vuna/doc/Newlands_Brochure.pdf (accessed on 15 June 2019).

42. Aqualima. 2018. Available online: http://aqualima.co.za/index.htm (accessed on 14 June 2019).

43. Bos, R.; Carr, R.; Keraita, B. Assessing and mitigating wastewater-related health risks in low-income countries: An introduction. In Wastewater Irrigation and Health: Assessing and Mitigating Risk in Low-Income Countries; Drechsel, P., Scott, C.A., Raschid-Sally, L., Redwood, M., Bahri, A., Eds.; Earthscan: London, UK; International Development Research Centre (IDRC): Ottawa, ON, Canada; International Water Management Institute (IWMI): Colombo, Sri Lanka, 2010; pp. 29-47.

44. Department of Water and Sanitation (DWAS) of South Africa. National Sanitation Policy 2016. 2016. Available online: http://www.dwa.gov.za/Documents/sanitation/17005SC_POLICY_National\%20Sanitation\% 20Policy\%202016\%20FINAL310117.pdf (accessed on 14 June 2019).

45. Department of Energy (DE) of South Africa. National Water Act. 1998. Available online: http://www.energy. gov.za/files/policies/act_nationalwater36of1998.pdf (accessed on 14 June 2019).

46. Steyn, M.; Jagals, P. Guidelines for the re-use of treated wastewater: Public health protection or denial of essential resources? In Proceedings of the WISA 2000 Biennial Conference, Sun City, South Africa, 28 May-1 June 2000; pp. 1-8.

47. eThekwini Municipality. Integrated Development Plan. 5 Year Plan: 2017/2018 to 2021/22. 2018. Available online: http://www.durban.gov.za/City_Government/City_Vision/IDP/Documents/IDP\%202017\%202018. PDF (accessed on 14 June 2019).

48. SDI South African Alliance (SASDI). Namibia Stop 8. 2012. Available online: https://www.sasdialliance.org. za/projects/namibia-stop-8-durban-kwazulunatal/ (accessed on 14 June 2019).

49. SDI South African Alliance (SASDI). Havelock. 2012. Available online: https://www.sasdialliance.org.za/ projects/havelock/ (accessed on 14 June 2019).

50. Green Building Council of South Africa. Improving Lives by Greening Low-Cost Housing. Case Study Report of the Cato Manor Green Street Retrofit. 2012. Available online: https://gbcsa.org.za/wp-content/ uploads/2018/01/Improving-lives-by-greening-low-income-homes-Case-Study-2012-FINAL.pdf (accessed on 21 June 2019).

51. Ruel, M.T.; Garrett, J.L.; Morris, S.S.; Maxwell, D.; Oshaug, A.; Engle, P.; Menon, P.; Slack, A.; Haddad, L. Urban Challenges to Food and Nutrition Security: A Review of Food Security, Health, and Caregiving in the Cities; Food Consumption and Nutrition Division, Discussion Paper no. 51; International Food Policy Research Institute: Washington, DC, USA, 1998; Available online: http://ebrary.ifpri.org/utils/getfile/collection/p15738coll2/id/ 125713/filename/125744.pdf (accessed on 19 May 2019).

52. Prain, G.; Lee-Smith, D. Urban Agriculture in Africa: What Has Been Learnt? In African Urban Harvest; Springer: New York, NY, USA, 2010; pp. 13-35.

53. UN-Women. Women's Key Role in Agricultural Production Emphasized. 2014. Available online: http://www. unwomen.org/en/news/stories/2014/10/sharefair-rural-women-technologies (accessed on 14 March 2019).

54. Food and Agriculture Organization of the United Nations (FAO). The State of Food and Agriculture. Women in Agriculture. In Closing the Gender Gap for Development; FAO: Rome, Italy, 2011; Available online: http://www.fao.org/3/a-i2050e.pdf (accessed on 14 March 2019).

(C) 2019 by the authors. Licensee MDPI, Basel, Switzerland. This article is an open access article distributed under the terms and conditions of the Creative Commons Attribution (CC BY) license (http://creativecommons.org/licenses/by/4.0/). 